\title{
Biomass Production and Carbon Sequestration by Cultivation of Trees under Hyperarid Conditions using Desalinated Seawater (Sewage Water)
}

\author{
Gerhard W. Ohlde ${ }^{1, *}$, Timo Stadtlander ${ }^{2}$ and Klaus Becker ${ }^{3}$ \\ ${ }^{1}$ Consultant, Gollenberg, Germany \\ ${ }^{2}$ Research Institute of Organic Agriculture, Department of Livestock Nutrition, Frick, Switzerland \\ ${ }^{3}$ University of Hohenheim, Institute of Animal Nutrition and Rangeland Management in the Tropics and \\ Subtropics, Stuttgart, Germany
}

\begin{abstract}
As growing economies - in particular in the Gulf region - use extreme and growing amounts of desalinated seawater for municipal purposes the use of produced waste waters is in the focus of science.

The fixation of atmospheric carbon-dioxide by a safe cultivation of trees using this slightly salty water sources is of increased importance in times of ongoing climate change.

Unfortunately, existing research relies on irrigation of trees in arid lands using ground water, any kind of precipitation, seasonal events like river flooding or a mix of them. To date no data support the biomass or tree production in total absence of natural precipitation and complete lack of ground water.

In this study, seven timber and fuelwood tree species, namely, Eucalyptus occidentalis En., Eucalyptus tereticornis Smith, Eucalyptus camaldulensis Dehnh., Eucalyptus gomphocephala DC., Eucalyptus grandis Hybr. Hill ex Maid, Tamarix aphylla (L.) Karst., Tamarix nilotica (Ehrenb.) Bunge were tested for carbon sequestration and biomassproduction. Above-soil and sub-soil parts were determined under two levels of drip-irrigation water supply: $25 \%$ and $50 \%$ of Evapotranspiration (ETo) over a period of two years and four months from planting to harvest. The trees were cultivated under hyper-arid climatic conditions using brackish irrigation water $\left(3.5 \mathrm{dS} \mathrm{m}^{-1}\right)$ on a research and development station in Arava, Israel.

Purified waste water from a seawater desalination plant (reverse osmosis) was applied after municipal use.

Eucalyptus gomphocephala DC. delivered the highest yields and had the highest water use efficiency, producing $70 \mathrm{t}$ of Dry Matter (DM) /ha/a under the higher irrigation level. Compared with the other species, E. gomphocephala DC. showed a $32 \%$ to $65 \%$ superior performance. Whereas, lower amounts of saline irrigation water were favoured by $E$. camaldulensis and T. aphylla - both producing more than $50 \mathrm{t}$ of DM/ha/a. Nevertheless, Tamarix, as a halophyte specialist plant, needed $30 \%$ less water for this growth.

Both Eucalyptus varieties mentioned before form a closed tree stand and reached a height of almost $10 \mathrm{~m}$, two years after planting. Regardless of the particular use of the produced timber, about $15-25 \%$ of the trees' total DM, approximately equal to the carbon-content, remains in the soil as long-term carbon-storage after harvesting the above ground biomass. Fast growing fuelwood tree species ensure a safe long-term biological fixation of carbon Irrigated with small amounts of saline waste water.
\end{abstract}

Keywords: Desert, de-salinated sewage water, water-use efficiency, Dry-Matter-production, Carbon-sequestration.

\section{INTRODUCTION}

As a matter of fact, the hottest and driest regions of the world power their development by desalinating seawater. In the absence of natural precipitation and groundwater or even surface water currents this probably forms the only way-out. Method of choice is "reverse osmosis", a process that requires enormous amounts of energy. Of course, lack of energy is not among the pressing problems of the Gulf states.

After production salts will have to be added to the water in order to provide fresh drinking water for human

*Address correspondence to this author at the Gerhard Ohlde, Consultant, Gollenberg, Germany; Tel: +49 170 5518375;

E-mail: gerhardohlde@gmail.com consumption and municipal supply. Use of the water will add additional salts and eventually slightly salty waste water is released. Approximately $90 \%$ of this valuable water source stays unutilized.

The cultivation of agricultural plants under dry conditions requires sufficient amounts of water. Fresh water (salinity $>0.2 \mathrm{dS} / \mathrm{m}$ ) from surface water currents, precipitation, local wells or groundwater within the reach of a plant's roots is limited, for economic reasons, for the production of agricultural crops. Unfortunately, these crops are sensitive to salts dissolved in irrigation water / brackish water.

Many publications report the suitability of nonagricultural crops / fuelwood / timber tree species, due to their water consumption and growth performance [1- 
3]. Eucalyptus species growing well under dry climatic conditions in areas with an annual precipitation of 100 $300 \mathrm{~mm}$ were tested against other local tree species. [4] for example compared E. camaldulensis with Albizzia procera (Roxb.) Benth., Acacia nilotica Del. and Azadirachta indica. E. camaldulensis showed a dry matter biomass production 2 to 8 times higher than local species, while water use (transpiration) was only 2 to 3 times higher. Of the investigated species, Eucalyptus achieved the top water use efficiency (WUE) $(0.77 \mathrm{~g} / \mathrm{l})$, equivalent to a consumption of 1300 $1 / \mathrm{kg}$ DM. Practical impact of results seems to be limited as the trial was designed as a flowerpot experiment in a greenhouse.

Some fuelwood tree species are known to tolerate moderate to heavy water salinity. A typical example was reported on the adaptability of Eucalyptus to salty groundwater [5]. Using irrigation water with a salinity of 2 or $5 \mathrm{dS} / \mathrm{m}$, on light soils, with deep $(4 \mathrm{~m})$ water tables, a nearly optimal balance was achieved with good wood production of Mean Annual Increments (MAI) in the range of 20 to $35 \mathrm{~m}^{3} / \mathrm{ha}$. In the presence of two different sources of water (in this case: groundwater and irrigation water/rainfall) the authors describe a distinct selection of trees against the more saline source. Groundwater use by trees shows a sharp decrease from low $(2 \mathrm{dS} / \mathrm{m})$ to medium $(5 \mathrm{dS} / \mathrm{m})$ level salinity and even less with salinities higher than 5 $\mathrm{dS} / \mathrm{m}$. This study was carried out in the Riverina Biogeographical Region, in south-west New South Wales, Australia. Annual rainfall varied from 300 to 500 $\mathrm{mm}$. Trees preferentially used fresh water from both surface and groundwater sources. If groundwater is saline, their use of surface water (rainfall and irrigation) increases.

Growing fuelwood species, under strict irrigation schemes with saline waste water, forms another option to increase the performance potential of trees under hyper-arid conditions in the absence of groundwater and natural precipitation. The growth and industrial diversification of the Arab countries' economies mainly stems from desalinated sea water. Future prospects in this respect seem to be very positive. Gulf Council Countries (GCC) are preparing to increase the capacity of their desalinated water production from currently 6000 million $\mathrm{m}^{3}$ per year to some 9000 million $\mathrm{m}^{3}$ per year in 2030 [6]. This shows that under severe hyperarid conditions desalinated water (reverse osmosis, $\mathrm{RO}$ ) can be used to irrigate trees after re-mineralization for municipal use (sewage water).
Based on the fact that all industrial, commercial and municipal developments in the arid zones of Arabia release enormous amounts of potential irrigation water the objective of our study is:

1. Testing promising tree species that thrive under harsh desert climatic conditions

2. Ranking these species according to:

- adaptation to saline irrigation water (salt tolerance)

- water use efficiency

- growth performance (dry matter production),

- carbon fixation.

\section{MATERIALS AND METHODS}

\subsection{Study Location}

The experiment had been conducted in An Naqb or Yotvata in the Southern Arava depression (392 m below sea level), $40 \mathrm{~km}$ north of Eilat, Israel, is located only a few hundred meters away from the Jordanian border $\left(29^{\circ} 53^{\prime} 44.16^{\prime \prime} \mathrm{N}\right.$; $\left.\quad 35^{\circ} 03^{\prime} 36.35^{\prime \prime} \mathrm{E}\right)$. It is characterized by hyper-arid climatic conditions like extreme irradiation throughout the year, summer temperature above $35^{\circ} \mathrm{C}$, in January $5-25^{\circ} \mathrm{C}, 2-3$ frost-nights, relative humidity in December $65 \%$, in July only $17 \%$, evaporation (pan evaporation) $3.200 \mathrm{~mm} / \mathrm{a}$; in January $3.4 \mathrm{~mm} / \mathrm{a}$, in August $13.1 \mathrm{~mm} / \mathrm{a}$, Evapotranspiration (ETo) according to the method of Penman-Monteith: $1890 \mathrm{~mm}$ [7], precipitation $25-30$ $\mathrm{mm} / \mathrm{a}$; erratic hail, wind speed: $\varnothing 29-38 \mathrm{~km} / \mathrm{h}$, maximum $76 \mathrm{~km} / \mathrm{h}$ with abundant sand storms

The tree planting area showed an extremely high evaporation potential as a combined effect of strong heat build-up in the soil and low relative air humidity.

\subsection{Plant Material}

Information on the suitability of selected tree species was taken from international literature [8-11] as well as from personal communication with renowned Israeli scientists (Ben-Asher, Ben-Gal, Berliner, Greenberg, Waisel, Yermiyahu and others).

Objective of our practical growth experiment was the ranking and performance of different promising tree species in order to identify and recommend species when grown under harsh desert conditions using small amounts of salty irrigation water. 
Table 1: Evaporation (mm/day) Measured as Class-A-Pan Evaporation According to the Penman-Monteith-Method as well as Maximum and Minimum Soil Temperatures $\left({ }^{\circ} \mathrm{C}\right)$ in $10 \mathrm{~cm}$ Depth

\begin{tabular}{|c|c|c|c|c|c|c|c|c|c|c|c|c|}
\hline & Jan & Feb & Mar & Apr & May & Jun & Jul & Aug & Sep & Oct & Nov & Dec \\
\hline $\begin{array}{l}\text { Class-A-Pan } \\
\text { evaporation } \\
(\mathrm{mm} / \text { day })^{*}\end{array}$ & 3.4 & 4.5 & 6.8 & 9.9 & 12.4 & 14.1 & 14.0 & 13.1 & 10.6 & 7.9 & 5.5 & 3.6 \\
\hline $\begin{array}{l}\text { Evaporation, } \\
\text { Penman-M. } \\
(\mathrm{mm} / \text { day })^{*}\end{array}$ & 2.2 & 2.9 & 4.3 & 5.9 & 7.2 & 8.2 & 8.2 & 7.4 & 6.1 & 4.3 & 3.1 & 2.2 \\
\hline $\begin{array}{c}\varnothing \text { max soil temp } \\
\mathrm{C}^{\circ} \text { in } 10 \mathrm{~cm} \\
\text { depth }^{\star *}\end{array}$ & 21 & 23 & 28 & 33 & 37 & 41 & 43 & 42 & 39 & 34 & 27 & 22 \\
\hline $\begin{array}{c}\varnothing \text { min soil temp } \\
\mathrm{C}^{\circ} \text { in } 10 \mathrm{~cm} \\
\text { depth }^{* *}\end{array}$ & 15 & 16 & 20 & 25 & 29 & 32 & 35 & 35 & 32 & 27 & 21 & 16 \\
\hline
\end{tabular}

${ }^{*}$ measured on site. ${ }^{* *}$ measured in Eilat. Source: www.ims.gov.il.

Tree species identified were Eucalyptus occidentalisis En., Eucalyptus tereticornis Smith, Eucalyptus camaldulensis Dehnh., Eucalyptus gomphocephala DC, Eucalyptus grandis Hybr. Hill ex Maid, Tamarix aphylla (L.) Karst., Tamarix nilotica (Ehrenb.) Bunge.

Seedlings of both Tamarix species were raised in the nursery of the research station and Eucalyptus seedlings were provided by nurseries of the Jewish National Fund (JNF).

Experimental design: a total number of 140 trees were planted in randomized plots of 10 each. For each variety 20 individual trees were planted, 10 were irrigated with a higher amount of water (50\% ETo) and 10 with a lower amount (25\% ETo). Salinity (electric conductivity) of irrigation water for all plots was $3.5 \mathrm{dS}$ $\mathrm{m}^{-1}$. Plots were planted in rows of $2.5 \mathrm{~m}$ width and a distance of $2 \mathrm{~m}$ between trees inside each row. This should allow sufficient space for growth without interference between trees as the trial was planned for more than two years. Available resources did not allow an increased number of plots (replications). The experimental design was focused on first-hand information on the ranking of growth performance. Number of replications was limited by space and the cost-rising complete harvest of all 140 trees by heavy equipment (diggers). This limitation was worthwhile as we gained data of the whole tree: above-soil and subsoil dry matter and carbon fixation performance.

\subsection{Soil Characteristics}

Soil in the planting plots stemmed from levelled dunes or alluvial sediments, predominantly sands, with locally varying contents of gravel, clay and silt. Soil texture of the experimental site can be described as loamy-silty sands. Silt content ranges from 1 to $18 \%$, clay content from 8 to $26 \%$. Water holding capacity is low: Permanent Wilting Point (PWP) is as low as $3-5$ vol.- $\%$, water-saturation at 36 vol.- $\%$, pore size distribution index of 0.55 .

Measured in three different depths, the soil showed a highly variable organic matter content, a neutral to slightly alkaline $\mathrm{pH}$, and a variable salinity mainly in the upper soil layers (Table 2).

Varying EC and organic matter was due to previous cultivations on the experimental farm.

\subsection{Irrigation Water}

Purified waste water from the Sabrah seawater desalination plant (reverse osmosis), north of Eilat, was

Table 2: Conductivity, pH and Organic Matter (Samples Taken at Random over all Cultivated Trial Plots) in Three Soil Depths

\begin{tabular}{|c|c|c|c|}
\hline Depth (cm) & Conductivity (EC) $\left(\mathbf{d S m}^{-1}\right)$ & pH & Organic Matter (\%) \\
\hline \hline $0-30$ & $0.4-6.7$ & $7.3-7.9$ & $0.9-3.0$ \\
\hline $30-60$ & $1.4-2.9$ & $7.9-8.2$ & $0.6-2.3$ \\
\hline $60-90$ & $0.7-1.7$ & $7.7-7.9$ & $0.7-2.1$ \\
\hline
\end{tabular}


pumped to the trial site after municipal use (sewage water) and used to irrigate the tree plots. Electric conductivity, ranged from $2.7 \mathrm{dS} \mathrm{m}^{-1}$ in winter to $3.8 \mathrm{dS}$ $\mathrm{m}^{-1}$ in summer. Based on Standard Formula this is equivalent to $1.9 \mathrm{~g}$ salt per litre of water.

Table 3: Physical and Chemical Characteristics of Irrigation Water

\begin{tabular}{|c|c|}
\hline $\mathrm{pH}$ & 8.1 \\
\hline Electric conductivity & $2.66\left(\mathrm{ds} \mathrm{m}^{-1}\right)$ \\
\hline Turbidity & $4.92(\mathrm{NTU})$ \\
\hline Chloride & $582 \mathrm{mg} / \mathrm{l}$ \\
\hline Sodium & $356 \mathrm{mg} / \mathrm{l}$ \\
\hline $\mathrm{Mg}$ & $54.5 \mathrm{mg} / \mathrm{l}$ \\
\hline $\mathrm{Ca}$ & $110 \mathrm{mg} / \mathrm{l}$ \\
\hline $\mathrm{K}$ & $21 \mathrm{mg} / \mathrm{l}$ \\
\hline Boron & $0.78 \mathrm{mg} / \mathrm{l}$ \\
\hline $\mathrm{Fe}$ & $<0.06 \mathrm{mg} / \mathrm{l}$ \\
\hline $\mathrm{Mn}$ & $0.05 \mathrm{mg} / \mathrm{l}$ \\
\hline $\mathrm{N}(\mathrm{ammonia})$ & $2.6 \mathrm{mg} / \mathrm{l}$ \\
\hline $\mathrm{N}\left(\mathrm{NO}_{3}\right)$ & $0.7 \mathrm{mg} / \mathrm{l}$ \\
\hline $\mathrm{P}$ & $2.8 \mathrm{mg} / \mathrm{l}$ \\
\hline
\end{tabular}

*Bastochem Company (personal communication).

Supply with macro nutrients was adjusted after analysing the nutrient contents of the irrigation water. Table 4 shows total macro nutrients necessary in the irrigation water to meet plant requirements (fertigation).

Table 4: Average Adjusted Macronutrient Content in Irrigation Water at $3.5 \mathrm{dSm}^{-1}$

\begin{tabular}{|c|c|c|c|}
\hline Irrigation water level & $\mathbf{N}\left(\mathbf{m g ~ l}^{-1}\right)$ & $\mathbf{P}\left(\mathbf{m g ~ l}^{-1}\right)$ & $\mathbf{K}\left(\mathbf{m g ~ l}^{-1}\right)$ \\
\hline \hline $25 \%$ ETo & 54.4 & 7.8 & 31.7 \\
\hline $50 \%$ ETo & 59.3 & 8.9 & 33.9 \\
\hline
\end{tabular}

Time Domain Reflectometry (TDR) and Time Domain Transmission (TDT) drip-irrigation technology provided constant and appropriate water supply.

\subsection{Duration of the Trial}

Tree cultivation was undertaken simultaneously for all species over a period of two years and 4 months.

\subsection{Harvest of Trees}

Those parts of trees above soil (stems, branches, twigs and leaves) were collected after cutting the stems with a chain saw right on the soil surface.
Subsoil parts of trees (roots) were excavated with a digger. Adherent soil particles were washed off with the help of a fresh-water hose. Fine roots remaining in the soil were collected with the soil, washed and separated by sieving ( $2 \mathrm{~mm}$ mesh size), followed by fresh weight and dry matter determination.

Fresh matter weight was determined by appropriate balances. Dry matter (DM) was determined by drying at $105^{\circ} \mathrm{C}$ until constant weight. This was followed by carbon determination.

\subsection{Carbon Determination}

Dried plant material was finely ground by an impeller cutting mill, Type SM 1 (Retsch, Haan, Germany), to pass a 1-mm-sieve. Carbon concentration was determined by Dumas combustion [12] with an automatic Vario $\mathrm{MAX} C N$-analyser (Elementar Analysesystem $\mathrm{GmbH}$, Hanau, Germany) following the procedure described by [13].

\subsection{Statistical Analysis}

The biomass data (Tables $\mathbf{5 a}$ and $\mathbf{5 b}$ ) show calculated means of dry matter production of whole trees, their above soil parts and below soil parts. Variation of individual tree performances is indicated by standard deviation (SD). Total losses are marked by asterixes and show the difficulty of computing complete sets of data as some of the tree/water amoutcombinations could not be measured due to partly complete losses.

\section{RESULTS}

Dry matter production per tree is presented in Tables $\mathbf{5 a}$ and $\mathbf{5 b}$. Although it has not been specifically tested, generally almost all species, except $T$. aphylla, produced more biomass DM in the plots with higher irrigation (50\% ETo). Tamarix aphylla, however, showed a contrary growth pattern and performed better under the lower irrigation scheme. Eucalyptus gomphocephala achieved by far the highest growth $(65.5 \mathrm{~kg} \mathrm{DM} /$ tree. Under conditions of relative water scarcity $(25 \%$ ETo) Tamarix aphylla ranked top together with Eucalyptus camaldulensis (50.2 kg resp. $54.2 \mathrm{~kg} \mathrm{DM} /$ tree).

High DM production of Eucalyptus species corresponds with total tree height and the diameter of the stem. The latter one might be of interest for postharvest timber use (Picture 1). Table 6 shows tree height and stem diameter at harvest. 
Table 5a: Dry Matter-Production, Irrigation Regime 50\% ETo and Salinity Level of $3.5 \mathrm{dSm}^{-1}$

\begin{tabular}{|c|c|c|c|c|c|c|}
\hline \multirow[t]{3}{*}{ Species } & \multicolumn{6}{|c|}{ DM-Production (kg/tree) at $50 \%$ ETo } \\
\hline & \multicolumn{2}{|c|}{ Above ground } & \multicolumn{2}{|c|}{ Below ground } & \multicolumn{2}{|c|}{ Whole tree } \\
\hline & kg & SD \pm & kg & SD \pm & kg & SD \pm \\
\hline E. occidentalis & 41.4 & 15.0 & 8.4 & 3.1 & 49.8 & 17,4 \\
\hline E. tereticornis & 42.7 & 25.8 & 6.9 & 5.2 & 49.6 & 29.8 \\
\hline E. camaldulensis & 34.4 & 26.9 & 13.2 & 9.1 & 47.6 & 35.2 \\
\hline E. gomphocephala & 54.7 & 11.9 & 10.9 & 3.5 & 65.5 & 14.2 \\
\hline E. grandis & 24.5 & 12.1 & 6.3 & 3.4 & 30.7 & 13.9 \\
\hline T. aphylla & 19.1 & 7.6 & 4.2 & 2.0 & 22.1 & 10.1 \\
\hline T. nilotica & 27.0 & 10.2 & 4.9 & 2.6 & 31.9 & 12.3 \\
\hline
\end{tabular}

Table 5b: Dry Matter-Production, Irrigation Regime 25\% ETo and Salinity Level of $3.5 \mathrm{dSm}^{-1}$

\begin{tabular}{|c|c|c|c|c|c|c|}
\hline \multirow[t]{3}{*}{ Species } & \multicolumn{6}{|c|}{ DM-Production (kg/tree) at $25 \%$ ETo } \\
\hline & \multicolumn{2}{|c|}{ Above ground } & \multicolumn{2}{|c|}{ Below ground } & \multicolumn{2}{|c|}{ Whole tree } \\
\hline & kg & SD \pm & kg & SD \pm & kg & SD \pm \\
\hline E. occidentalis & 20.8 & 13.7 & 4.8 & 2.7 & 25.6 & 17.4 \\
\hline E. tereticornis & 17.5 & 8.3 & 4.8 & 2.5 & 22.3 & 10.5 \\
\hline E. camaldulensis & 37.5 & 22.0 & 16.8 & 9.3 & 54.2 & 27.3 \\
\hline E. grandis & 4.3 & 3.4 & 1.4 & 0.7 & $5.3^{*}$ & 4.2 \\
\hline T. aphylla & 43.1 & 31.4 & 7.2 & 5.7 & 50.2 & 36.9 \\
\hline T. nilotica & 5.7 & 3.8 & 1.0 & 0.7 & $6.7^{* *}$ & 4.4 \\
\hline
\end{tabular}

${ }^{*} 30 \%$ total losses. ${ }^{* *} 20 \%$ total losses.

The impressive height obtained after only 2 years and 4 months after planting clearly shows the suitability of the selected tree species to use saline waste water for irrigation and their potential to establish closed vegetation stands fast (Picture 2).

Among all tested Eucalyptus species, Eucalyptus camaldulensis showed an outstanding ability to adapt to salinity $\left(3.5 \mathrm{dSm}^{-1)}\right.$ combined with low water supply (Table 5b). However, Tamarix aphylla needed $30 \%$ less water than Eucalyptus camaldulensis (Table 7). This results in the best water use efficiency for the low water regime applied.

Under the high water regime (50\% ETo), Eucalyptus gomphocephala obviously ranks first in wood DM

Table 6: Tree Height and Stem Diameter at Harvest $(\mathrm{cm})$ at Two Irrigation Levels $(25 \%$ and $50 \%$ ETo)

\begin{tabular}{|c|c|c|c|c|}
\hline \multirow{2}{*}{ Species } & \multicolumn{2}{|c|}{$\mathbf{5 0 \%}$ ETo } & \multicolumn{2}{c|}{ 25\% ETo } \\
\cline { 2 - 5 } & height & Stem diameter & 500 & 11.1 \\
\hline \hline E. occidentalis & 740 & 13.6 & 590 & 11.9 \\
\hline E. tereticornis & 900 & 14.6 & 800 & 14.3 \\
\hline E. camaldulensis & 730 & 13.1 & 570 & 670 \\
\hline E. gomphocephala & 790 & 15.9 & 513 & 8.1 \\
\hline E. grandis & 975 & 11.8 & 290 & 16.7 \\
\hline T. aphylla & 400 & 12.4 & 14.0 & \\
\hline
\end{tabular}




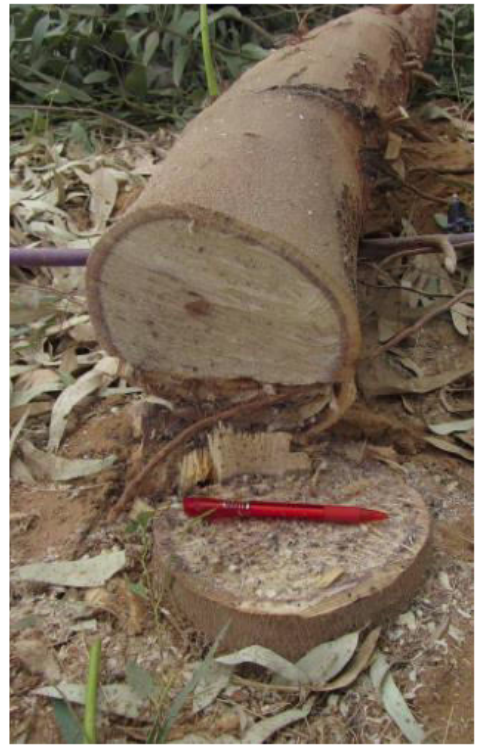

Picture 1: Stem of Eucalyptus camaldulensis at harvest.

production (Table 8) and even used the lowest amount of water per kg among all tested trees (Table 9). Under a low water regime (25\% ETo), however, Eucalyptus camaldulensis and Tamarix aphylla were found to be most efficient DM-producers with highest water-useefficiencies (Table 9).

Table 7: Irrigation Water Supply at Two Irrigation Levels (25\% and $50 \%$ ETo)

\begin{tabular}{|c|c|c|}
\hline \multirow{2}{*}{ Species } & $\mathbf{5 0 \%}$ ETo & $\mathbf{2 5 \%}$ ETo \\
\cline { 2 - 4 } & & $\mathbf{m}^{\mathbf{3}}$ water $/ \mathbf{h a} / \mathbf{a}$ \\
\hline \hline E. occidentalis & 11447 & 5344 \\
\hline E. tereticornis & 11446 & 5411 \\
\hline E. camaldulensis & 11585 & 5470 \\
\hline E. gomphocephala & 11661 & 5425 \\
\hline E. grandis & 11659 & 3742 \\
\hline T. aphylla & 7948 & 3778 \\
\hline
\end{tabular}

Table 8: Dry Matter Productivity (t DM/ha/a, Based on 2500 Trees/ha) and Water Applied (m³/ha/a) at $25 \%$ and 50\% ETo

\begin{tabular}{|c|c|c|c|c|}
\hline Species & \multicolumn{2}{|c|}{$50 \%$ ETo } & \multicolumn{2}{|c|}{$25 \%$ ETo } \\
\hline E. occidentalis & 53.4 & 11447 & 24.7 & 5344 \\
\hline E. tereticornis & 53.2 & 11446 & 23.9 & 5338 \\
\hline E. camaldulensis & 51.1 & 11585 & 58.2 & 5411 \\
\hline T. aphylla & 23.7 & 7948 & 53.9 & 3742 \\
\hline T. nilotica & 34.2 & 8008 & 7.2 & 3778 \\
\hline
\end{tabular}


Table 9: Water Use Efficiency, Litres of Applied Water per kg DM Produced

\begin{tabular}{|c|c|c|}
\hline Species & $\mathbf{5 0 \%}$ ETo & 25\% ETo \\
\hline \hline E. occidentalis & 214 & 216 \\
\hline E. tereticornis & 215 & 93 \\
\hline E. camaldulensis & 227 & 179 \\
\hline E. gomphocephala & 166 & 952 \\
\hline E. grandis & 354 & 69 \\
\hline T. aphylla & 335 & 524 \\
\hline T. nilotica & 234 & \\
\hline
\end{tabular}

Table 10: Carbon Fixation (kg) per Tree at Harvest and Distribution of Carbon Fixed in above Soil Plant Parts and Roots

\begin{tabular}{|c|c|c|c|c|c|c|}
\hline \multirow{2}{*}{ Species } & \multicolumn{3}{|c|}{$\mathbf{5 0 \%}$ ETo } & \multicolumn{3}{|c|}{$\mathbf{2 5 \%}$ ETo } \\
\cline { 2 - 7 } & $\begin{array}{c}\text { kg carbon in } \\
\text { above soil parts }\end{array}$ & $\begin{array}{c}\text { kg carbon in } \\
\text { subsoil parts }\end{array}$ & $\begin{array}{c}\text { kg carbon in } \\
\text { whole tree }\end{array}$ & $\begin{array}{c}\text { kg carbon in } \\
\text { above soil parts }\end{array}$ & $\begin{array}{c}\text { kg carbon in } \\
\text { subsoil parts }\end{array}$ & $\begin{array}{c}\text { kg carbon in } \\
\text { whole tree }\end{array}$ \\
\hline \hline E. occidentalis & 20.5 & 4.0 & 24.5 & 9.9 & 2.3 & 12.2 \\
\hline E. tereticornis & 21.1 & 3.3 & 24.4 & 8.3 & 2.3 & 10.6 \\
\hline E. camaldulensis & 17.0 & 6.3 & 23.6 & 17.9 & 8.0 & 25.9 \\
\hline E. gomphocephala & 27.1 & 5.2 & 32.3 & 11.7 & 1.8 & 13.5 \\
\hline E. grandis & 12.1 & 3.0 & 15.1 & 2.0 & 0.7 & 2.7 \\
\hline T. aphylla & 9.5 & 2.0 & 11.5 & 20.5 & 3.4 & 23.9 \\
\hline T. nilotica & 13.4 & 2.3 & 15.7 & 2.7 & 0.5 & 3.2 \\
\hline
\end{tabular}

average carbon content in the DM of above-soil plant parts and $47.6 \%$ in sub-soil plant parts.

Thorough sieving and washing of the root system of the trees after excavation indicates how much of a tree's DM and carbon content is located in the root system and the shoots (Tables $5 \mathbf{a}, \mathbf{5 b}$ and 10 ).

\section{DISCUSSION}

Ongoing loss of arable land, the growing scarcity of water for plant irrigation, the use of today's underutilized dry lands and sewage water resources puts the knowledge of the suitability of plants thriving under hyper-arid conditions, irrigated with salty waters, into the future focus. Forty years ago, practical recommendations did not even mention the word salt or salinity and rather focused on different soil qualities under different levels of natural precipitation [14].

Results of this study contribute to the global fight against climatic change and show that in the arid parts of the globe, where two thirds of fossil fuels are pumped to the surface, the enormous amounts of desalinated sewage water can be used to fix the carbon released into the atmosphere after burning, at least partly.

Selected tree species tested in this experiment originated from locations of arid / hyper-arid climatic conditions. This applies to latitude, temperature and extreme water evaporation levels. For successful afforestation it is essential to select seeds / provenances from a climatic zone similar to that of the envisaged planting area $[15,16]$. Tree species tested here were all provided by domestic nurseries. Very similar if not identical environmental conditions are found in the GCC region.

The decision to use moderately saline sewage water was based on the fact that salt water is contaminating traditional fresh water sources like aquifers and wells to a growing extent by intrusion of seawater. Extensive research work shows that saline water is detrimental to agricultural and floral crops [1719]. In contrast to these, fuelwood crops are reported to have a higher tolerance to salinity $[15,20]$. To our knowledge, existing data describes either experiments 
under natural precipitation and/or access to groundwater. There is a lack of information on tree cultivation under the type of arid conditions described here, using saline water as an exclusive source of irrigation. Nevertheless, basic information will be needed for practical afforestation efforts in desert regions using saline water sources that are available and could be used to raise non-agricultural crops.

Trees in this experiment show impressive DM productivity and effective use of water (Table 8). The forest and secondary wood processing industry is predominantly interested in aboveground tree biomass, namely the stems / trunks of trees. In temperate zones, mean average increments of about 10 to $15 \mathrm{t} / \mathrm{ha} / \mathrm{a}$ are achieved [21]. Under the managerial and environmental conditions of the reported experiment up to $70 \mathrm{t} / \mathrm{ha} / \mathrm{a}$ (Table 8 ) were achieved.

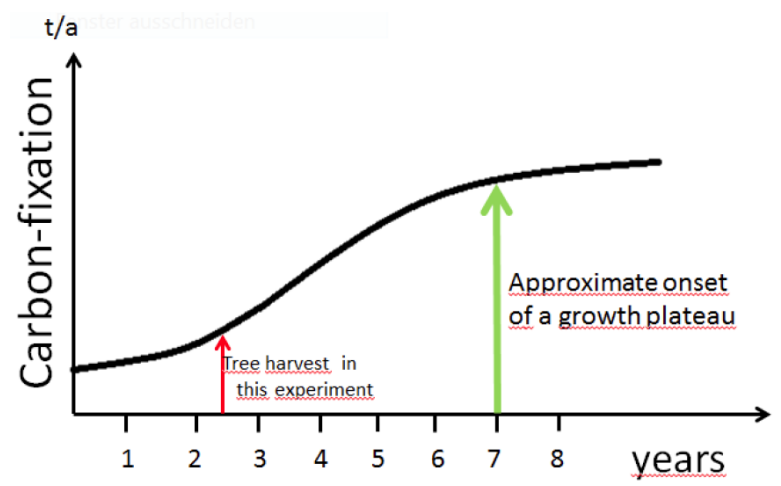

Graph 1: Typical growth curve of trees in the subtropics.

Biomass Sustainability and Carbon Policy Study. www.thebioenergysite.com/articles/700/biomass.

Dry matter production and concomitant carbon fixation generally increases during the first years and will reach a plateau after about 6 to 7 years (Graph 1). Concluding from this, rotation periods of $6-7$ years can be recommended. [22] reports a mean annual volume increment (MAl) of $30 \mathrm{~m}^{3} \mathrm{ha}^{-1} \mathrm{yr}^{-1}$ with Eucalyptus camaldulensis - also in Israel - under irrigation conditions (Lamprecht, 1990). This MAI, based on a residual moisture content of $14 \%$ and a specific mass of $650 \mathrm{~kg} / \mathrm{m}^{3}$ [23], is equivalent to $16.7 \mathrm{tDM} / \mathrm{ha} / \mathrm{a}$ and is notably outperformed by $E$. camaldulensis in our experiment (Table 8).

In our trials DM productivities of Eucalyptus species ranged up to $70 \mathrm{t} \mathrm{DM} / \mathrm{ha} / \mathrm{a}$ in the high water regime and $58 \mathrm{t} \mathrm{DM} / \mathrm{ha} / \mathrm{a}$ in the low water regime (Table 8), around a fourfold higher production than $16.7 \mathrm{t}$ in the high water regime. This favours the use of moderately saline sewage water in the applied amounts. Nevertheless, regarding water use efficiency (WUE), Tamarix aphylla consumed even $30 \%$ less water achieving only $4 \mathrm{t}$ less $\mathrm{DM} /$ ha/a compared with $E$. camaldulensis being the top performer in the irrigation variant of $25 \%$ ETo (Table 8 ). Interestingly, only $T$. nilotica notably benefitted from a higher water supply (50\% ETo) and showed almost a five-fold increase in biomass production. Tamarix aphylla, however, reacted contrariwise and reduced its biomass production substantially under the higher water supply (50\% ETo) compared to the lower water supply (ETo) (Tables 5a, 5b and 8). To date, available field data were obtained under non-comparable environmental and management conditions. For example, Zahid et al., 2010, reports fresh water data from a greenhouse pot experiment lasting one year with $E$. camaldulensis. They determined a WUE of $1299 \mathrm{l} / \mathrm{kg}$ produced DM whereas, E. camaldulensis in our trial consumed $93 \mathrm{l} / \mathrm{kg}$ in variant $25 \%$ ETo and 227 $\mathrm{l} / \mathrm{kg}$ in variant $50 \%$ ETo (Table 10 ).

The forest production or timber / fuel industry focuses on the above soil parts of trees after harvest, whereas environmental aspects include mid- and longterm storage of carbon as well. As plants are known to safely fix atmospheric carbon-dioxide during growth, energetic use of trees' biomass frees the same amount of carbon as the plant previously fixed as a result of photosynthesis, generally called a neutral carbonbalance.

According to our data, approximately $25 \%$ to $30 \%$ of a plant's carbon production is located in the roots and thus remains in the soil after harvesting the trees (Table 11). This leads to a negative carbon-balance, which is advantageous in terms of global warming. Tree cultivation forms an effective tool for safe biological carbon-sequestration. It will not be enough to reduce carbon emissions. Ambitious environmental targets need the long-term fixation of current atmospheric carbon-dioxide. Policymakers are beginning to understand the scale of carbon dioxide removal that is required to keep global warming "well below $2{ }^{\circ} \mathrm{C}$ ". This understanding must now be translated into policies that give businesses the incentive to research, develop and deploy the required technologies [24].

Both, wood producers as well as carbon-traders should focus on those tree species that perform best under a given or possible irrigation scheme. At watering intensities of $50 \%$ ETo, E. gomphocephala clearly offers the highest DM or timber yields and fixes the most amount of carbon in the roots. At this watering level both Tamarix species could not compete with the 
Table 11: Annual Dry Matter Production of above-Soil Parts (t DM/ha/a, Base 2500 Trees/ha) and Concomitant Amounts of Carbon Remaining in Root Dry Matter (t/ha/a) at $25 \%$ and $50 \%$ ETo

\begin{tabular}{|c|c|c|c|c|}
\hline \multirow{2}{*}{ Species } & \multicolumn{2}{|c|}{$\mathbf{5 0 \%}$ ETo } & \multicolumn{2}{c|}{$\mathbf{2 5 \%}$ ETo } \\
\cline { 2 - 4 } & $\begin{array}{c}\text { DM above soil } \\
\text { t/ha/a }\end{array}$ & $\begin{array}{c}\text { carbon remaining } \\
\text { in soil (t/ha/a) }\end{array}$ & $\begin{array}{c}\text { DM above soil } \\
\text { t/ha/a }\end{array}$ & $\begin{array}{c}\text { carbon remaining in } \\
\text { soil (t/ha/a) }\end{array}$ \\
\hline \hline E. occidentalis & 44.4 & 4.3 & 22.3 & 2.5 \\
\hline E. tereticornis & 45.8 & 3.5 & 18.8 & 2.5 \\
\hline E. camaldulensis & 36.9 & 6.8 & 40.2 & 8.6 \\
\hline E. gomphocephala & 58.7 & 5.6 & 26.4 & 1.9 \\
\hline E. grandis & 26.3 & 3.2 & 4.6 & 0.8 \\
\hline T. aphylla & 20.5 & 2.1 & 46.2 & 3.6 \\
\hline T. nilotica & 29.0 & 2.5 & 6.1 & 0.5 \\
\hline
\end{tabular}

tested Euclyptus species in dry matter production or carbon fixation in the roots. In general, Tamarix growth mainly consists in the increase of the shoot. At limited water availability (25\% ETo) E. camaldulensis offers good timber production ( $40 \mathrm{t} / \mathrm{ha} / \mathrm{a})$ and high long term carbon fixation in the roots - $8.6 \mathrm{t} / \mathrm{ha} / \mathrm{a}$ which represents $45 \%$ of the tree's total carbon content. [25] found an accumulated carbon content in an old forest in Southern China. They determined more than $14 \mathrm{t}$ carbon / ha / a over a period of 24 years in the top 20 $\mathrm{cm}$ of the soil, the most active horizon for trees' root activities. Their findings correspond with our results. Although we harvested the trees after a comparably short growth period, we measured up to almost $9 \mathrm{t}$ of carbon fixed in parts below the soil. It is assumed that the origin of Soil Organic Carbon (SOC), as determined in the soil under well matured deciduous trees in China, is the root system of the trees. A growing percentage of carbon-dioxide in the atmosphere will result in intensified plant growth - including their root systems. For example, in the case of Tamarix aphylla, shed leaves and twigs contributed considerably in our own trial to the immission of $C$ into and onto the surface of the soil. Per ha and year, $3.2 \mathrm{t} \mathrm{C}$ dropped to the ground with the leaves, showing a C-content of $48.7 \%$ in DM. E. gomphocephala will fulfil economic expectations for the utilization as timber as well as utilizing the tree's carbon fixation capacity [26]. The calorific value of $1 \mathrm{~m}^{3}$, when used as a fuel, will be equivalent to $280 \mathrm{I}$ oil. The value will be higher as construction timber or veneer. When incorporated into the trade with carbon-credits, the environmental future trade value of tree cultivation might even exceed the value of the wood. Current prices for the sequestration of $1 \mathrm{t}$ of $\mathrm{CO} 2$ are as low as $5.50 €$. The amount of available wastewater in GCC regions might irrigate at a watering intensity of $50 \%$ ETo an area of half a million ha in theory (base data Table 9 and a current seawater desalination in GCC of 6000 million $\left.\mathrm{m}^{3} / \mathrm{a}\right)$. In terms of carbon credits such cultivation would be equivalent to a monetary income of $190 €$ per ha and year for E. gomphocephala and $139 €$ for E. camaldulensis.

A low water irrigation scheme (25\% ETo) facilitates a plantation size of more than a million ha. Here, $E$. camaldulensis should be selected in case timber is in the focus of the management. In this case, $E$. camaldulensis would fix a carbon equivalent to $153 €$ per ha and year.

If fuelwood is favoured, Tamarix aphylla would further increase the potential cultivation area to more than 1.5 million ha.

Table 11 offers for the first time a composition of relevant key data that enables strategic decision making for the layout of biomass production in arid environments. According to [27], a plantation of the size of $100 \mathrm{~km}$ by $100 \mathrm{~km}$ could lead to a reduction of temperature by $1^{\circ} \mathrm{K}$, under similar climatic conditions, and/or enhancement of precipitation by approximately $11 \mathrm{~mm}$ and $30 \mathrm{~mm}$, averaged over the plantation during summer time in Oman and the Sonora, USA, respectively. Changes in rainfall were complex and tended to occur in streaks where convection was initiated. The increase in rainfall is substantial in summer and can amount to $160 \mathrm{~mm}$ along the streaks. This localization of the water cycle would be very beneficial for the biosphere in this region.

Practical considerations on plantation design most likely recommend a mixed cultivation / intercropping of different tree species for phyto-sanitary reasons and fire resistance. This might be a cultivation of Eucalyptus trees intercropped with Tamarix aphylla.

\section{CONCLUSION}

The simultaneous availability of land that has been unused to date as well as only marginally utilized vast 
amounts of moderately saline waste water in the GCC region, offers the opportunity to cultivate irrigated fuelwood/timber plantations. This study provides key data for the afforestation of hundreds of thousands of hectares. It identifies and ranks appropriate tree species. In an irrigation scheme of $50 \%$, ETo Eucalyptus gomphocephala ranked first in terms of biomass production, water-use efficiency and carbon sequestration in this study. Under lower watering conditions (25\% ETO) Eucalyptus camaldulensis performed outstanding with respect to timber production and carbon sequestration. At this level, however, Tamarix aphylla equals DM-production of $E$. camaldulensis with a much higher water use efficiency.

\section{REFERENCES}

[1] Cohen Y, Adar E, Dody A, Schiller G. Underground water use by Eucalyptus trees in an arid climate. Trees - Struct Funct 1997; 11: 356-362. https://doi.org/10.1007/s004680050096

[2] Deans JD, Munro RC. Comparative water use by dryland trees in Parklands in Senegal, in: Agrofor Syst 2004; pp. 2738.

https://doi.org/10.1023/B:AGFO.0000009402.06475.81

[3] Qadir M, Boers TM, Schubert S, Ghafoor A, Murtaza G. Agricultural water management in water-starved countries: Challenges and opportunities. Agric Water Manag 2003; 62: 165-185. https://doi.org/10.1016/S0378-3774(03)00146-X

[4] Zahid DM, Shah FUR, Majeed A. Planting Eucalyptus camaldulensis in arid environment - is it useful species under water deficit system? Pakistan J Bot 2010; 42: 1733-1744.

[5] Cox J, Morris J, Paydar Z, Loane W, Huth NI, Snow VO, McEwan KE, Walker GR. Water balance and economics of irrigated eucalypts in areas with shallow saline groundwater. A report for the RIRDC / Land \& Water Australia / Joint Venture Agroforestry Program 2005; 199: 74. www.rirdc.gov.au/reports/AFT/05-199.pdf.

[6] Dawoud MA, Al Mulla MM. Environmental Impacts of Seawater Desalination: Arabian Gulf Case Study. Int J Environ Sustain 2012; 1: 22-37.

https://doi.org/10.24102/ijes.v1i3.96

[7] Allen M, Pereira RG, Raes LS, Smith D. Crop evapotranspiration - Guidelines for computing crop water requirements - FAO Irrigation and drainage paper 56 FAO, Rome, 1998.

[8] Tomar OS, Minhas PS, Sharma VK, Singh YP, Gupta RK. Performance of 31 tree species and soil conditions in a plantation established with saline irrigation. For Ecol Manage 2003; 177: 333-346. https://doi.org/10.1016/S0378-1127(02)00437-1

[9] Foroughbakhch F, Háuad LA, Cespedes AE, Ponce EE, González N. Evaluation of 15 indigenous and introduced species for reforestation and agroforestry in northeastern Mexico. Agrofor Syst 2001; 51: 213-221. https://doi.org/10.1023/A:1010702510914
[10] Dickinson N, Brwarow G, Kelly GM. Promising high-value hardwood plantation tree species for the dry tropics of Queensland, Proceedings, in: Conf. 'Prospects High-Value Hardwood Timber Plant. Dry Trop. North. Aust., 2004.

[11] FAO, Ecocrop, (n.d.). http://ecocrop.fao.org/ecocrop/srv/en/ home (accessed May 3, 2018).

[12] Dumas A. No Title. Ann Chim 1826; 33: 342.

[13] Naumann C, Bassler R. Bestimmung mittels DUMASVerbrennungsmethode, in: Die Chem. Untersuchung von Futtermitteln, 2012.

[14] Weber FR. Reforestation in Arid Lands, Vita Publication, 1977.

[15] Turnbull JW. The ecology and variation of Eucalyptus camaldulensis. For. Occas. Pap. For. Genet. Resour. Information, FAO, Rome, Italy 1973; 2.

[16] Boland JD, Brooker DJ, Chippendale MIH, Hall GM, Hyland $\mathrm{N}$, Johnston BPM, Kleinig RD, McDonald DA, Turner MW. Forest Trees of Australia, 5th ed., CSIRO, Collingwood, Australia, 2006

[17] Niu G, Rodriguez DS, Aguiniga L. Effect of saline water irrigation on growth and physiological responses of three rose rootstocks. HortScience 2008; 43: 1479-1484. https://doi.org/10.1073/pnas.1212431110

[18] Pasternak D, Danon A, Aronson JA, Benjamin RW. Developing the seawater agriculture concept. Plant Soil 1985; 89: 337-348. https://doi.org/10.1007/BF02182252

[19] Shannon MC, Grieve CM. Tolerance of vegetable crops to salinity. Sci Hortic (Amsterdam) 1998; 78; 5-38. https://doi.org/10.1016/S0304-4238(98)00189-7

[20] Rahman MM, Rahman MA, Miah MG, Saha SR, Karim MA Mostofa MG. Mechanistic Insight into Salt Tolerance of Acacia auriculiformis: The Importance of Ion Selectivity, Osmoprotection, Tissue Tolerance, and $\mathrm{Na}+$ Exclusion. Front Plant Sci 2017; 08. https://doi.org/10.3389/fpls.2017.00155

[21] BMEL - Bundesministerium für Ernährung und Landwirtschaft, Der Wald in Deutschland, 2. Auflage 2016; 53

[22] Lamprecht $\mathrm{H}$. Silviculture in the tropics. Tropical forest ecosystems and their tree species - possibilities and methods for their long-term utilization 1989.

[23] Little ELJ. Common Fuelwood Crops 1983; 355 http://pdf.usaid.gov/pdf docs/PNAAN216.pdf.

[24] Peters GP, Geden O. Catalysing a political shift from low to negative carbon. Nat Clim Chang 2017; 7: 619-621. https://doi.org/10.1038/nclimate3369

[25] Zhou G, Liu S, Li Z, Zhang D, Tang X, Zhou C, Yan J, Mo J. Old-growth forests can accumulate carbon in soils. Science 2006; 314(80): 1417.

https://doi.org/10.1126/science.1130168

[26] Smith R, Renton M, Reid N. Growth and carbon sequestration by remnant Eucalyptus camaldulensis woodlands in semi-arid Australia during La Niña conditions. Agric For Meteorol 2017; 232: 704-710. https://doi.org/10.1016/j.agrformet.2016.10.014

[27] Becker K, Wulfmeyer V, Berger T, Gebel J, Münch W. Carbon farming in hot, dry coastal areas: An option for climate change mitigation. Earth Syst Dyn 2013; 4: 237-251. https://doi.org/10.5194/esd-4-237-2013

Received on 14-05-2019 Accepted on 04-07-2019

Published on 15-07-2019

DOI: https://doi.org/10.30635/2415-0142.2019.05.4

(C) 2019 Ohlde et al.; Journal of Agriculture Food and Development.

This is an open access article licensed under the terms of the Creative Commons Attribution Non-Commercial License (http://creativecommons.org/licenses/by-nc/3.0/) which permits unrestricted, non-commercial use, distribution and reproduction in any medium, provided the work is properly cited. 